\title{
The Two Cultures at Cambridge
}

\author{
PETER LACHMANN \\ Christ's College, Cambridge University, Cambridge, UK. \\ Email: pj11000@cam.ac.uk
}

\begin{abstract}
Charles Percy Snow was born in Leicester in 1905 and - like his fictional alter ago Lewis Eliot - determined from an early age to be remembered. The essays in this issue, some 60 years after he first wrote about 'The Two Cultures', give testimony that in this respect he has been successful. There is still merit in his essential contentions that there are graduates in the humanities who remain out of touch with scientific developments and science graduates who don't read novels. But the world has changed: the computer revolution and the World Wide Web have permitted far broader access to each of the two cultures. While the split between the humanities and the sciences may have grown less, another fissure has become prominent: the sharp divide between those I call the true children of the European enlightenment and those who reject these values, the 'fideists'. This argument began at Christ's College, Cambridge.
\end{abstract}

\section{Snow at Christ's}

C.P. Snow was educated at the Alderman Newton Grammar School and took his first degree at the local University College there. He went on to Cambridge on a scholarship in 1928 to undertake research in physical chemistry. He obtained his PhD in 1930 and was elected a Fellow of Christ's College in the same year. However, this part of his career was not a success and after a Nature paper on a new method of synthesizing Vitamin A, which turned out to be incorrect, he withdrew from further scientific research. I've often thought that Snow had always wanted to be a novelist and had been attracted to science as an easier path to Cambridge, on which he was so keen. In those days, you needed better grades for a Cambridge scholarship in the humanities than in science.

Snow remained a Fellow of Christ's from 1930 to the early 1950s and was elected to an Honorary Fellowship in 1966. Even after he gave up academic life for a career in the Civil Service, politics and writing novels, he always maintained some connection with his old College and particularly with his Leicester friend, the eminent historian Jack Plumb, with whom he corresponded for the rest of his life. In a recent history of Christ's College, a chapter by the historian David Cannadine is devoted to 'the era of Todd, Plumb and Snow'. ${ }^{1}$ This gives an excellent background account of the two 
cultures and the situation in post-war Britain as seen from the point of view of these three eminent scholars. Alexander Todd was a Nobel laureate in Chemistry (1957) and an extremely influential figure both in Cambridge and on the political scene. He was Master of Christ's from 1964 to 1978 and a member of the House of Lords. His Cambridge reputation was matched only by that of Nevill Mott (another Nobel laureate, in Physics). The saying went: 'Todd thinks he's God, Mott knows that he's not'. While I know nothing about Todd's - or Mott's - novel-reading habits, Todd was a fine linguist. Chemist Todd and historian Jack Plumb, who followed Todd as Master from 1978-1982, could have presented Snow with perfect models of The Two Cultures, but that would have done neither of them justice.

I share with C.P. Snow the privilege of being a Fellow of Christ's, although we did not overlap as I was first elected in 1962 and I met Snow only once. One of the great positive features of the Cambridge Collegiate system is that both the students and, perhaps particularly, the Fellows form a community which encompasses all academic disciplines. My memories of my own early years as a Fellow there were that I spent far more time interacting with the historians around Jack Plumb, who included the future luminaries Quentin Skinner, Simon Schama and John Burrow; with the economist James Meade; and the Elizabethan English scholar Graham Hough than I did with my scientific colleagues in the college. By the 1960s Christ's was certainly not a site of division between the two cultures!

Snow's picture of college life, as described in three of his Strangers and Brothers series of novels - The Light and the Dark, The Masters and The Affair - did not endear him to all of his contemporary fellows and he became a controversial figure at Christ's. At the outbreak of the Second World War he entered the Civil Service and was active in recruiting scientists to work in the war effort. This seems to have provided the basis for his views on education in England among scientists and what he regarded as their more than somewhat inadequate knowledge of the humanities. His views on the inadequate scientific knowledge of humanities students may similarly have been based on his experience of the civil servants with whom he worked, who were likely to have been largely humanities graduates and who may indeed have been largely ignorant of 'science', and probably sometimes innumerate. Very much more recently, Professor Lisa Jardine, who was then Head of the Healthcare and Fertilisation and Embryology Authority complained, at a lecture she gave in Christ's, that at least one of her staff was unable to do decimals! She and her father, Jacob Bronowski, were outstanding figures bridging the two cultures. Bronowski had already written in The Commonsense of Science in 1951 that 'It has been one of the most destructive modern prejudices that art and science are different and somehow incompatible interests'; and his later TV series 'The Ascent of Man' in 1973 was a hugely successful endeavour to explain science to the world at large.

\section{Two Cultures, Indeed}

When Snow analyses his Two Cultures he is contrasting the culture of the humanities with the culture of the natural sciences. When he talks about intellectuals and the 
humanities, he is talking predominantly about the literary humanities. 'Not to have read War and Peace, La Cousine Bette and La Chartreuse de Parme' - he says in his 1956 New Statesman piece - is not to be educated. Having myself read only the first of these makes me feel suitably chastened. I do however like to read history but Snow says very little about historians or social scientists or economists; and music and the performing arts also do not figure among his humanities scholars. Scientific culture is, in an analogous way, restricted almost entirely to physics, and the biological sciences are largely ignored. He regards ignorance of the Yang and Lee experiment of 1957 showing 'contradiction of parity' as culpable - and I again feel chastened - but makes no mention of Watson and Crick's 1953 paper on the structure of DNA which did so much to fire the revolution in molecular biology, the implications of which have spread across - and beyond - the two cultures into the consciousness of the general public.

Snow's real complaint was about the excessive specialization of English education where, from the age of 16 onwards, pupils specialize in generally just four subjects, usually either in the humanities or the sciences. He compared this unfavourably with the situation in the United States where specialization occurs much later, and with Russia, whose education system also impressed him. It must be said that Snow's diagnoses of the different educational systems were not supported by evidence in the way that one might expect from someone of his background. He did not apply any measures of scientific or humanities achievement, whether by publication analysis, patents granted, Nobel prizes, or other (all possibly dubious) parameters of esteem, when comparing those educated in the UK with those in Russia or the United States. His conclusion that society would benefit by more mutual understanding between the humanities and the sciences is, however, not in dispute.

The impact that was made by the fuller publication of his ideas in the Rede lecture in 1959 - which followed upon an earlier shorter publication in the New Statesman in 1956 - attracted a great deal of public attention, not least in the United States. This public attention was accentuated by the intemperate attack on him by F.R. Leavis, an English don in Cambridge, in his Richmond lecture of 1962. Leavis did not admire Snow as a novelist, nor did he think that scientists provide a cultural presence. $\mathrm{He}$ probably found more sympathy for the former point of view than for the latter.

Looking back at Snow's Rede lecture after almost 60 years, what in it still seems relevant today? There is certainly still merit in his essential contentions that there are graduates in the humanities who remain out of touch with scientific developments and science graduates who don't read novels. But the world has changed hugely. Snow did not have the gift to look into the future. This is not restricted to the two cultures. In Philip Snow's biography of his older brother, he reproduces extensive correspondence between the two in the 1930s and during the Second World War when Philip was in Fiji. ${ }^{2}$ Charles' firmly stated gloomy prognostications on what was about to happen were in most instances quite wrong - which must have been a great relief to him as well as to posterity.

For example, Snow pays almost no attention to the growing role of women, particularly in the sciences. They were only mentioned very briefly right at the end of his 
Rede lecture. This meshes with a very curious letter to his brother congratulating him on the birth of his daughter in 1947 where he says that 'One advantage of a girl is that you don't have to bother about her education'. He did however bother about his son's education. In 1965, when he was a minister in the Ministry of Technology in Harold Wilson's Labour government, he was damaged politically by having a spat in the House of Lords with Viscount Eccles about sending the young Snow to Eton rather than to a state school.

He certainly failed to appreciate the huge influence that public service broadcasting would make to educating the public about science and about literature and the other humanities. Radios were ubiquitous in the late 1950s but universal access to television in the home was still to come in the UK. The computer revolution and the World Wide Web were still far in the future too, and their influence on public education has been extraordinary. It is now possible to access detailed information on virtually any topic. Inevitably, attempts have been made to exploit this resource by those whose agenda is not to provide unbiased information, but this has not seriously undermined the value of the World Wide Web. Certainly a resource such as Wikipedia, which gives (nearly always) accurate and informative accounts on almost any subject you can think of, has done much to make it easier to bridge the two cultures and to have at least a passing acquaintance with cultures other than one's own.

\section{Enlightenment and its Enemies}

If the 'Two Cultures' split between the humanities and the sciences may have grown less, another quite different division into two cultures has become prominent. I find this split even more troubling and dangerous to human progress and well-being than the one described by Snow. I refer to the sharp divide between those whom I would call the true children of the European Enlightenment and those who reject these values. The adversaries of reason hold views of the world that depend neither on evidence or observation but are based on deference to authority, usually 'religious orthodoxies' derived from their holy books. The term 'religious' is here used in a broad sense to include such secular religions as Marxism, with Das Kapital, and Nazism, with Mein Kampf as their holy books, in addition to the more conventional religions. The conflict between these cultures is not new but it is astonishing that it has persisted and become stronger in today's world, where everyday life is dominated by the technological outcomes of modern science, whether in communications both of people or of knowledge, or of modern medicine, or of the ability to travel to the moon or to send spacecraft to other planets.

Although it is probably now rare to find people who believe that the world is flat in view of the fact that one can fly right round it in an airplane, it remains the case that there remain a large number of people who still adhere to the Genesis account of the creation of the world and who, in particular, reject evolution of species by natural selection. It has been reported that some $40 \%$ of the population of the United States are still creationists and that the teaching of evolution was forbidden in Turkey by President Erdogan in 2017. 
In the United Kingdom, a prominent advocate of rejecting the values of the enlightenment is the Prince of Wales, as reported in the Times in 2010:

Long regarded as the foundation of contemporary political and intellectual culture, by way of influences ranging from the American Declaration of Independence to the scientific method as embraced from Isaac Newton on, the Enlightenment was based on the belief that all society's ills could be vanquished by the application of reason.

Its seminal figures included the likes of Descartes, Leibniz, Locke, Voltaire and Rousseau.

To Prince Charles, however, it is old hat.

'I thought, "Hang on a moment". The Enlightenment started over 200 years ago. It might be time to think again and review it. We cannot go on like this, just imagining that the principles of the Enlightenment still apply now. I don't believe they do. But if you challenge people who hold the Enlightenment as the ultimate answer to everything, you do really upset them.'

'I believe it is of crucial importance to work with, in harmony with nature, to rediscover how it is necessary to work with the grain of nature, as it is necessary to work with the grain of our humanity,' he said. 'What is the point of all this clever technology if at the end of the day we lose our souls, and the soul of nature of which we are a part? (Valentine Low, The Times, London, 4 February 2010).

An even more extreme rejection of reason can be found on a plaque in the Megalo Meteora monastery in Greece:

RATIONALISM IS AN EXCESSIVE CONFIDENCE IN OUR OWN POWERS OF REASON, ITS ELEVATION TO THE SUPREME AND ABSOLUTE VALUE. IN ESSENCE, IT IS A FORM OF DISBELIEF, A LACK OF FAITH. IT IS NOT A SIMPLE SIN, BUT A SINFUL STATE OF MIND, A SINFUL VIEW OF LIFE. RATIONALISM IS THE MOST TYPICAL AND MOST EVIL MANIFESTATION OF PRIDE, CONCEALED BENEATH ALL OUR OTHER SINS, LATENT IN ALL OUR ACTIONS, POISONING ALL OUR GOOD DEEDS, LEADING TO AN ABSOLUTE BELIEF IN THE SUPREMACY OF THE SELF, AND FINALLY IS THE INABILITY TO REPENT - THEREBY CLOSING THE DOOR TO DIVINE MERCY.

Reason here is not just an error but a sin. This may not be the general view of the Greek Orthodox Christian church but it is disturbing to see it expressed at all in the twenty-first century. Those who reject reason also frequently fiercely reject scientific advances that interfere with their interpretation of what is 'natural'. This includes most reproductive technologies, genetic modification, whether of food plants or animals, and sometimes even vaccination against infectious disease.

These new two cultures can be given the names of 'the rational culture' whose adherents will be called sceptics, as opposed to 'the faith-based culture' whose adherents will be called fideists. They are in many ways opposites and incompatible but they do have one feature in common, which is that they regard the human species as standing in stark contrast to the rest of the biological world. In the case of the faith culture, this is due to the belief that man is made in the image of God, and even where the fideists have come to believe that physical evolution has occurred, they believe 
that at some stage in the development of the human species mankind was ensouled and given a significance and long-term meaning that does not extend to other animals.

For the sceptics, what is (almost) unique about the human species is that it has adopted cultural evolution as a mechanism for behavioural progress. Although cultural evolution exists in a primitive form in some of man's nearest relatives, the chimpanzee and the bonobo, in its highly developed form it is unique to humans and has allowed the human species to make huge advances in their understanding of the world and in all aspects of their physical lives at a speed that is totally inconsistent with the speed at which changes occur in genetic evolution. It was the development of language and of purposive speech that makes humans unique. Purposive speech differs from communication among most animals who respond to stimuli such as the presence of food, the approach of predators, the courting of a potential mate, etc., by programmed responses. Humans, on the other hand, can choose what it is they wish to communicate. It may well be that purposive speech is the best surrogate marker for consciousness, in which case full consciousness would also be limited to humans. Cultural evolution in humans, undoubtedly for long periods of time, took place only by example and then by oral traditions so that what they had learnt could be passed on far more widely and far more rapidly. This was revolutionized again with the invention of writing about four to five thousand years ago, and yet again, even more dramatically perhaps, with the coming of electronic communication in the last century.

The use of cultural evolution confers both huge advantages on, but of course also presents great dangers to, the human species. On the one hand, there seems to be almost no limit to the extent to which it has been able to increase the number of humans and allow them to occupy more and more of the world, to live in many cases in much greater security and comfort, and to obtain an understanding both of the physical and biological world that is quite certainly absent in all other forms of life on this planet. On the other hand, it is quite extraordinary that humans seem throughout history to have indulged in endless warfare with each other. This may be a consequence of cultural evolution, which requires that there are mechanisms in place that maintain a particular pattern of behaviour in a reasonably constant form over enough individuals and enough generations that natural selection can work on it.

\section{The Gods of War}

What we know of what ancient religions taught dates back only since records became available: about the last 5000 years. But there is archaeological evidence to suggest that religions go back for at least 70,000 years or more. That part of religion, which would be important for cultural evolution, is its prescription, the 'thou shalts' and the 'thou shalt nots' that all religions have. As was eloquently pointed out by Kellett in $1933,{ }^{3}$ religious prescriptions are remote from moral concerns: 'religion was a series of external actions or abstention from action, intended to propitiate supernatural powers.' It said nothing as to what we today call 'good conduct' but discusses such 
matters as what one should eat, what one should wear, and how one should behave in a variety of different situations. The reason why these prescriptions were originally formulated is usually obscure, but one can see quite clearly that many would have survival value, usually with regard to infectious disease of which little or nothing was known when the prescriptions were first brought into use. If religions are to provide the basis of cultural evolution, then they must maintain their prescriptions separately and independently, and this may well account for the enduring persistence of religious intolerance. That this competition between different religions causes and, as far as we know, has always caused such hatred and violence is both depressing and alarming. A visitor from another planet in the seventeenth century would have been amazed to see the brutal warfare between Protestants and Catholics who worship the same God and subscribe to the same holy book. Four centuries on, similar visitors would be amazed to see the brutality of the struggle between Shia and Sunni Muslims who again worship the same God and the same Prophet and have the same holy book.

Hugely destructive wars are not new. Within recorded history there have always been huge losses of life in warfare. The conquests of the Mongols in the thirteenth century are a good example of probably similar forms of warfare that go back beyond recorded history. However, with the advent of increasingly destructive weapons based on atomic fission and fusion and the possibility of biological forms of warfare of unprecedented destructive power, the danger to the civilized world has grown enormously. The political situation in 2018, even in the Anglo-Saxon world, is not such as to give one much reassurance that the rational culture is making a great deal of progress.

Another area of difference between the faith-based and the rational culture is in their views of morality and ethics, these being the guardians of good behaviour. Faith-based culture invariably believes in some sort of natural law and some sort of eternal ethic as laid down in its particular religion. These, of course, are not always identical but they are believed to be permanent and unchanging. The rational culture cannot accept that. It is quite clear that ethics have changed even over historical periods of time and unless we are prepared to believe that our ancestors were all moral imbeciles, one must recognize that ethics themselves have evolved. This process can give rise to terrible consequences. The twentieth century saw the (admittedly temporary) success of moral systems of quite appalling kinds, whether it be the Nazi regime in Germany or the Stalinist regime in the USSR or the Pol Pot regime in Cambodia. This demonstrates that cultural evolution, like genetic evolution, has no fixed purpose and responds to pressures that are active at the time. As the world has grown smaller and communications, both of ideas and people, have become much more rapid, the danger that this implies has also been enhanced.

Another fundamental difference, which largely, but not uniformly, divides these two cultures is their view on life persisting in any form after death. Most fideists believe in continued life after death, although usually without any clear view of how this could be brought about or indeed how one would relate to one's own various ages or indeed to one's ancestors. Some have believed in reincarnation either as other humans or as animals. The sceptics on the whole believe, along with the original form 
of Buddhism, that after life comes extinction. Buddhists believed that there had to be repeated cycles of incarnation until one had rid oneself of all desires, at which time one could achieve Nirvana, which is extinction. Modern sceptics do not believe in reincarnation and take the view that the extinction of desire occurs with death rather than before.

Belief in some form of attractive existence after death provides comfort to the bereaved and those close to death. However, there can be little doubt that it also serves as an inducement to engage in warfare in support of one's God(s), which is the likely explanation of why this belief has survived so widely. It would clearly now be hugely in the interests of mankind for belief in an afterlife that rewards those who die in warfare to end, but the current epidemic of Jihadist terrorism shows that there is no sign of this happening within at least one faith-based culture.

If our civilization is long to survive, it seems essential that these two cultures learn to live in mutual tolerance. How this can be brought about is difficult to see. One approach that would certainly help would be to persuade the fideists that, just as sex should be confined to consenting adults in private, so religion should be confined to worshiping their God(s) on the relevant day of the week and should not define their secular existence. This is not so far from Christ's injunction to 'Render therefore unto Caesar the things which are Caesar's; and unto God the things that are God's' that it should be impossible to achieve, but there has again been no sign at all of any progress in this direction in the first two decades of the current millennium.

\section{References}

1. D. Reynolds (Ed.) (2005) Christ's - a Cambridge College over Five Centuries (London: Macmillan), pp. 181-226.

2. P.A. Snow (1982) Stranger and Brother (London: Macmillan).

3. E.E. Kellett (1933) A Short History of Religions, Chapter 1 (London: Victor Gollantcz).

\section{About the Author}

Sir Peter Lachmann, FRS, a Fellow of Christ's College, Cambridge, has been Vice President and Biological Secretary of the Royal Society. Sir Peter is an eminent experimental immunologist who has worked out how the complement system works in the human body. He has also produced the historic Royal Society's 1998 report on genetically modified crops. 